\title{
Rebuilding downtown: The importance of activity generators in downtown revitalization
}

\begin{abstract}
Patrick McConnell
This paper looks at recent history of small-metro downtowns, examining their fall from prominence and attempts at revitalization. The paper suggests activity generators, such as events, venues and attractions, are vital parts of the initial focus of downtown revitalization attempts where office-building employment has remained strong but a disconnect has emerged between the office workers and the rest of the downtown. The impact of activity generators is explored via a case study of London, Ontario. The case study concludes that financial incentives are insufficient on their own but play an important supporting role when paired with effective activity generators.
\end{abstract}

Keywords: downtowns, urban revitalization, farmers markets, public libraries, revitalization, sporting events

This paper looks at recent history of small-metro downtowns, examining their fall from prominence and attempts at revitalization. The paper suggests activity generators, such as events, venues and attractions are vital parts of the initial focus of downtown revitalization attempts where office-building employment has remained strong but a disconnect has emerged between the office workers and the rest of the downtown.

\section{Historic Nature of Downtowns}

The early twentieth century was a period of massive transformation in the distribution of Canada's population. In 1901, only $37.5 \%$ of the population lived in urban areas, but by 1941, it was $54.5 \%$. In real terms, Canada's urban population tripled from just over 2 million to almost 6.3 million (Bourne, 2000). This dramatic increase in population, along with construction innovation, led to a building boom that reshaped Canadian downtowns. "During the boom periods of 1900-13 and the 1920s small office districts formed at the core of central areas" (Gad \& Matthew, 2000, p. 252). During this period, department stores thrived and became the heart of new retail and entertainment districts were located near the newly built office buildings. "In major cities the new retail clusters also became the locations of the newly emerging, mass entertainment facilities" (Gad \& Matthew, 2000, p. 253).

Residential areas had retail locations serving their populations but stores requiring a larger population base were located downtown. "Day-to-day shopping was carried out close to home in corner stores and neighbourhood commercial strips. Meanwhile, high-order goods were typically purchased downtown” (Jones, 2000, p. 407).

This Central Business District (CBD) remained the dominant business and retail area of cities into the decade after the end of the Second World War. "Downtown was still by far the major 
center of economic and social activity in the early 1950s" (Ford, 2003, p. 55). In mid-sized cities during this period, "big department stores and movie palaces were normally concentrated on one or two streets, as was the sense of a busy, vibrant center city. First class office buildings occupied a few more nearby streets, but the CBD was still quite compact" (Ford, 2003, p. 56).

The early 1950s could be considered the golden age of downtown: "a time when lots of people lived close to downtown and still used its facilities on a fairly regular basis for major shopping trips, services, and recreation. For neighbourhoods close to downtown, the central business district was the neighborhood center. Cities were compact well into the twentieth century, and so it was not difficult to walk or ride the trolley from close-in communities" (Ford, 2003, p. 43). A second massive transformation in the distribution of Canada's population was about to take place.

\section{History of Urban Sprawl and Suburbanization}

The period since the Second World War has seen a tremendous growth in the size of Canadian cities, both in terms of population and area. "In 1951 the greater Toronto area (the GTA) had 1.5 million residents; by 1996 it had over 4.6 million, a massive threefold increase. Yet, over the same period, the physical size of the urban region grew by a staggering six to seven times, as population densities declined and almost all urban activities consumed more space" (Bourne, 2000, p. 34).

Suburbanization has been driven by changes in transportation. "The shape and fate of central cities in the second half of the twentieth century tended to reflect the growing influence of the automobile and the internationalization of the economy" (Grant, 2000, p. 457). It should be noted that every major advance in transportation has left an imprint on urban design, "beginning with the horse drawn omnibus in the 1820's and progressing from there to electrified streetcars and subway trains, to the high-speed suburban railways and most overwhelmingly of all, to the automobile" (Smith, 2000, p. 309).

The independence afforded by automobile ownership freed commuters from high-density residential areas found downtown and along transit corridors and led to a new form of middleclass residences. Bigger homes could be built on larger plots of land in all residential neighbourhoods. "In the postwar period, consumer demand for single family homes on large lots has resulted in low-density residential developments with concentrations of commercial and other services in suburban shopping malls" (Jamieson et al., 2000, p. 463). Furthermore, these new neighbourhoods were no longer intermixed with industry and retail outlets. "North American theories of city planning crystallized around a conception of generous low-density lifestyles, with homes segregated from industry and business" (Olson, 2000, p. 234). As populations moved farther and farther from the core, industry and retail became increasingly decentralized as reliance on automobiles grew. "[Suburbanization] places homes far from places 
of work and shopping and other daily activities, forcing reliance on motorized transport" (Jamieson et al., 2000, p. 465).

Automobiles also influenced the distribution of retail within suburbs. Now instead of only serving their immediate neighbourhoods, retail could now locate at major intersections and serve a much greater population. Retail outlets previously limited to downtowns could now support themselves in suburban shopping malls. In time, with shifts in population distribution and cheaper suburban land, shopping malls began to outperform the downtown retail district.

\section{Hollowing out of the core}

The shift in population to the suburbs led to the emergence of suburban shopping malls as retailers followed their customer base. "Downtown districts deteriorate as services and activities are diverted to suburban malls and higher-income households move to the suburbs" (Jamieson et al., 2000, p. 463). As stores left, downtown became less of an attraction for potential customers and a downward spiral began. More and more stores left and the "bustle of the central city in the early 1950s had, by the late 1970's, given way to clear signs of malaise" (Grant, 2000, p. 458).

As stores left, downtowns increasingly became less attractive places to live. "The decline of retail shopping in CBDs has detracted from the appeal of downtowns as residential areas" (Blair and Carroll, 2009, p. 218-219). As residents left, the quality of housing deteriorated and the residents that remained or replaced those who left were poorer than their predecessors had been. 'Houses will often undergo some adaptive change when they filter to a lower-income group. One important reason for the change in the housing stock is that lower-income groups may be unable to afford the same maintenance levels as the previous higher income group. Also, lower-income groups may wish to divide houses to accommodate more people" (Blair \& Carroll, 2009, p. 207). As socially disruptive conditions increase in lower-income areas (Taylor-Butts, 2009, p.14), safety concerns would quickly drive the former commercial customer base away from downtown and into malls.

Further contributing to downtown decline, vacant former residential and retail buildings were often torn down and replaced with parking lots to service the daily commuters to office buildings. Many of these lots have been held in low maintenance states as the "owners may be speculating that the land will be suitable for a different use in the future, and therefore, land values will increase faster than the return in the current use" (Blair \& Carroll, 2009, p. 191). With lot owners unwilling to sell, and new investment in residential and retail buildings downtown limited, developers have found that it's more profitable to build new on a suburban lot than to renovate existing buildings or teardown old buildings and build new ones in their place.

\section{Downtown's Strengths and Weaknesses}

When drafting policies to revitalize downtowns it is important to determine the region's strengths and weaknesses. Policies should look to build on existing and potential strategic 
advantages and not try to compete with other regions of the city in activities in which downtown has significant disadvantages.

While all downtowns and cities are different, there are some common strengths and weaknesses shared by downtowns:

Strengths

- Downtowns are usually centrally located within cities and as such can minimize travel times for customers drawn from throughout the city.

- While retail and factories have relocated to most cities' peripheries, office buildings have retained a strong presence in many downtowns, providing a large daytime population and customer base.

- Downtowns frequently offer unique shopping and dining opportunities with more local independently run retail outlets and restaurants than is found in large suburban malls and big box stores comprised of national chains.

- Downtowns are also frequently home to parks and plazas capable of hosting outdoor events and festivals and large venues for hosting concerts, theatre, conventions and sports.

- Most cities have transit hubs downtown providing alternative commuting options, decreasing congestion and allowing downtown to draw individuals from a larger area.

\section{Weaknesses}

- The higher density of buildings downtown causes higher property and rent costs as compared to suburban locations. This influences the type of retail that would consider downtown locations.

- Higher density also reduces the availability of parking for downtown stores and restaurants as they lack the space for parking immediately outside their establishments.

- If retail and restaurant establishments downtown are unable to create and maintain linkages with the office buildings, downtowns can come to be seen as a place of office buildings only; where workers remain in their offices during the day and leave downtown as soon as they finish work.

- Downtowns frequently have areas with groups of individuals loitering on a consistent basis. These areas are often near transit hubs and social assistance offices and discourage potential shoppers from visiting the area.

\section{Revitalization Policies}

Cities have many policy options when looking to revitalize their downtown. The mix a city chooses will depend on its individual strengths and weaknesses but some policies have been successful in many cities and are worth considering: 
- Tax incentives can encourage development and renovations by delaying and phasing in the tax increases resulting from the increased property value. By lowering the initial tax burden of a project, developers and business owners have greater incentive to invest in their properties and businesses, increasing the downtown's attractiveness to customers and potential investors.

- Cities are also able to encourage investment through grants and subsidized loans with programs that offer to cover a percentage of a project's cost or offer a below market loan. Again, by increasing the project's profitability, a city is able to encourage investment downtown.

- A wide range of Public Works projects can help revitalize downtowns, from new arenas $\&$ theatres to better sidewalks \& more lighting. Public art displays are also popular choices. These projects aim to make downtown more appealing to residents and visitors.

- Regulatory changes are another important tool for cities to consider. Shortening the application time required and simplifying the process for opening a business downtown will assist entrepreneurs in starting new ventures. Allowing more flexible land use can increase population density and encourage new residential areas downtown. Renovating empty industrial buildings into lofts has proven successful in many cities, creating new neighbourhoods within historic buildings.

\section{Importance of Attractions}

Filion et al. (2004) highlights the importance of synergies between the different sectors of downtowns. Their survey on the health and characteristics of small-metro downtowns found that "The foremost generalized lesson to be distilled from our selected downtowns is alarmingly simple: Their success can be attributed to an ability to attract people and assure they remain in their midst to pursue many of their activities" (p. 339). A frequent comment from their respondents was the "importance of a resident population and of a wide variety of land uses to assure 24-hour activity" (p. 332). This paper looks to highlight the importance of activity generators in downtown revitalization, specifically as a means of creating synergies between employment and other land uses.

Even after retail moved to the suburbs, many downtowns remained centres of corporate business. These corporations still valued a downtown location with easy access to public buildings (city hall, courts, government offices), banks, and other offices because it reduced transportation time when commuting to meetings throughout the day. "The need for a central location is due primarily to the importance of face-to-face contact among executives. Individuals in these occupations [finance, legal, and administrative functions] may require frequent, short-notice meetings. Since the time of lawyers, financiers, or executives is valuable, their transportation costs are high" (Blair and Carroll, 2009, p. 188).

As decentralized retail became the norm, office workers had fewer synergies with downtown and began shopping closer to home on evenings and weekends. Following the departure of 
department stores to newly built malls near residential areas, they no longer drew workers from their offices during lunch hour and after work to shop downtown. As foot traffic decreased, smaller stores began to experience difficulty and were force to close or move.

As the success of revitalization strategies relies on the existence of foot traffic, the first challenge and opportunity in downtown revitalization is getting those who work downtown to view downtown as more than just their place of employment. This is where the importance of activity generators is the greatest. Activity Generators are venues that attract large numbers of people either daily such as markets and libraries or for live events such as arenas or theatres.

Downtowns are a natural fit for the venues and events that act as activity generators as they are centrally located and have the public transit and parking for such venues (while parking is often limited, downtown parking for office workers can be reused as events are usually held outside of business hours). Events get people walking around, shopping and eating downtown and therefore provide a catalyst to private retail investment downtown. The success of downtown events creates a vibrancy of activity downtown that feeds on itself creating more retail investment and residential investment as downtown transforms into a desirable destination.

As Jones (2000) put it: "At the most basic level, retailers locate in response to market conditions. If the population/income mix or market potential is appropriate, retail development will occur" (p. 406). Activity generators are important catalysts in building the critical mass of market potential needed to attract retail investment.

\section{Case Study - London Downtown Millennium Plan}

\section{Background}

Like many cities of its size, London's downtown had been a thriving retail district but three suburban malls built between 1970 and 1985, along with a poorly integrated downtown mall, resulted in a major decline in downtown shopping. With retail outlets closing, the area's vibrancy was lost and "was increasingly perceived as dirty, dangerous, and unappealing" (Hume, 2014, p. 65). With the bankruptcy of Eaton's and the Bay's decision to move to the north end's Masonville Mall, downtown lost its two remaining anchor stores. The City's previous attempts at revitalization (mainly through financial incentives) were somewhat successful but failed to bring back the vibrance. Street level vacancies were increasing and buildings were being demolished to create surface parking; after losing an estimated $\$ 60$ million in taxable assessment, "City Council decided to take a major leadership role by investing in this depressed area" (City of London \& Downtown London, 2014, p. 1).

\section{Plan}

The plan that emerged was the Downtown Millennium Plan, a \$110 million investment in a variety of projects downtown. The three biggest were a downtown arena, a new central library 
and a new downtown market. All three replaced older rundown buildings and the arena (home to the OHL's London Knights) was relocated downtown from south of the 401, an area distant from much of the city's population.

These projects were joined by the creation of a MainStreet program (now Downtown London), investments in the waterfront at the Forks of the Thames, an arts incubator, and a downtown lighting project.

\section{Result}

The three main projects have been extremely successful.

Budweiser Gardens (originally the John Labatt Centre) "drew 654,207 people in 2012 and another 675,631 people in 2013" (City of London, 2014, p. 16). For London Knights' games “a sell-out crowd of 9,000+/game is virtually assured" (Hume, 2014, p. 58). In their previous arena of 5,000, the Knights had been unable to fill the seats. Part of this success should be attributed to new ownership developing a significantly more successful hockey team. Since 2011, Budweiser Gardens has also been the home to the National Basketball League of Canada's (NBL) London Lighting, who are now averaging 5,000 attendees per game and have occasionally drawn crowds of over 8,000 (AM980). Budweiser Gardens has also hosted two Memorial Cups (2005 and 2014), the Brier (2011), the Tournament of Hearts (2006), as well as the World Synchronized Skating Championships (2007) and the 2013 World Figure Skating Championships (Hume, 2014, p. 69). None of these events would have come to London without Budweiser Gardens. The arena has also hosted many concerts for world-renowned superstars such as Cher, Elton John and Shania Twain.

Across the street from Budweiser Gardens sits the Covent Garden Market, whose presence at Talbot and King Streets dates back to 1845. The building, completed in 1999, has a design inspired by the original building built in 1853. It has become a popular lunch destination with two sit-down and 16 takeout restaurants. The market is also home to a variety of merchants selling products ranging from speciality coffee, tea, cheeses \& chocolates, fresh produce, artwork and locally made children's clothing. It is also home to two community non-profits and a children's theatre troupe. The plaza out front houses outdoor seating and a farmers market during the summer and a skating rink in the winter. "The Covent Garden Market has averaged between 25 and 30 thousand visitors weekly. Sales at the end of 2013 were \$15,900,000" (City of London, 2014, p. 3).

The new Central Library relocated to Galleria Mall (now Citi Plaza) in 2002, filling a vacancy left when The Bay moved to Masonville Mall. "The Central Library in both 2012 and 2013 saw over 900,000 visitors, over 1.5 million items borrowed, and over 3,000 programs run" (City of London, 2014, p. 3). The library is also home to "a 400-seat theatre that is booked most nights a year, is host to the London Arts Council and the Heritage Council, as well other community organizations, and provides several heavily-used meeting rooms" (Hume, 2014, p. 68). The 
three-storey facility also has an outdoor plaza and reading area and serves as the mall's gateway to Dundas Street.

The effect these projects have had on their surrounding areas has been remarkable. Several new bars and restaurants are located near Budweiser Gardens. The area across King Street from The Covent Garden Market is lined with restaurants and the Central Library has been credited with saving the Galleria Mall from bankruptcy (Hume, 2014, p. 68). Furthermore, the current value assessment for Downtown London rose $61 \%$ from 2004 to 2013, an increase of \$400 million.

A large component of the increase in the current value assessment is the construction of new housing downtown, specifically the Renaissance Tower at the corner of King and Ridout Streets across from Budweiser Gardens. Completed in 2009, the 28 storey building with 278 units "rented so quickly, Tricar decided to begin construction of the second tower almost two years earlier than originally planned" (Daniszewski, 2012). The second tower--comprised of condominiums--was complete in 2013, adding another 199 units at Ridout and York Streets with a multi storey indoor parking lot with greenspace on its roof, connecting the two buildings. The success of the two buildings has prompted developers to investigate other potential apartment buildings downtown, including a parking lot at King and Clarence Streets where a developer is currently investigating building two 20 plus storey towers and a third smaller building (Meyers, 2014).

In total, Downtown London's population increased over 50\% from 2001 to 2011, with $72 \%$ of the population growth occurring among individuals 20-44 (City of London, 2014, p. 19). Furthermore the income growth of those living downtown has outpaced the rest of the city as "the increase in median household income over the decade for the city was $22 \%$; in the downtown the increase was more than double that at 46\%" (City of London, 2014, p. 21).

In 2014, the City of London's Downtown Millennium Plan was one of two winners of the International Downtown Association's (IDA) Pinnacle Award for planning. The IDA said in a news release that London received the Pinnacle Award "for demonstrating excellence in downtown management. The Millennium Plan is a wonderful example for all cities to emulate" (McLeod, 2014).

\section{Lessons}

In their submission to the IDA, London discussed previous attempts at downtown revitalization that had focused on financial incentives such as interest free loans for building code upgrades and façade improvements, waiving development charges and parking requirements for residential units, and a tax rebate for improved and new buildings. While London found these attempts to be reasonably successful, the city claims they had not been "enough to stimulate the rebirth of London's downtown alone" (City of London \& Downtown London, 2014, p. 1). Recognition of the previous Community Improvement Plan (C.I.P) shortcomings prompted the development of the Downtown Millennium Plan. 
Discussing the results of the Downtown Millennium Plan, the city found that "[o]nce the City's investment started to manifest itself on our streets, the C.I.P. took hold. Many developers and individual building owners began participating in the incentives program and still do to this day" (City of London \& Downtown London, 2014, p. 2). While the previous plans had been necessary and beneficial to London's downtown they were insufficient to encourage more Londoners to visit downtown or office workers to develop a connection to the downtown outside of their office. Catalysts are required to attract people and prompt the improvements that have been achieved, and to begin changing people's perception of downtown.

\section{Conclusion}

As the hearts of their communities, downtowns have a powerful influence on residents' perceptions of their cities. As the home of business and entertainment, downtowns represent their communities to visitors. A vibrant downtown attracts the talent and resources for cities to grow and prosper.

As cities try to revive downtowns suffering the effects of suburbanization and urban sprawl, it is vital that they include activity generators to re-establish connections between the downtown and the rest of the community. Financial incentives to spur private investment are beneficial but as seen in the case of London, Ontario they are often not sufficient on their own. Business owners and developers look for areas where demand will make their investment profitable and for that, they need customers. Activity generators strengthen the effect of other revitalization efforts by acting as catalysts, drawing people downtown and changing perceptions of the area. When people are present, investment will follow. Since 2001, London has experienced $\$ 3$ of private investment for every $\$ 1$ of public funding (City of London \& Downtown London, 2014, p. 2).

Downtown is where everything comes together. It is an attic where we store our past; it is a landscape which illustrates our cultural aspirations and technological possibilities; it is a street where we meet and learn to interact with a wide variety of people; and it is a challenge that hones our skills and keeps us on our toes. Life without downtown might be comfortable in some ways, but something would be missing.

Larry R. Ford, America's New Downtowns, page 43

\section{Author biography}

Patrick McConnell lives in London, Ontario where he is a Program Liaison Officer with the Ontario Ministry of Community and Social Services and Ministry of Children and Youth Services. Patrick has a Bachelor of Science in Economics and a Bachelor of Arts in Political Science from the University of Tulsa and a Master of Arts in Economic Policy from Boston University. 


\section{References}

AM980 (2015, Jan 12). London Lightning Set Attendance Record - Again. AM980. Retrieved from http://www.am980.ca/2015/01/12/london-lightning-attendance/

Bourne, L.S. (2000). Urban Canada in Transition to the Twenty-First Century, in Bunting, T, Filion, P (Eds.), Canadian Cities in Transition: the Twenty-first Century, 2nd Edition (p. 26-52). Toronto: Oxford University Press.

Blair, J.P. \& Carroll, M.C. (2009). Local Economic Development: Analysis, Practices, and Globalization. Los Angeles: Sage Publications.

City of London (2014). State of the Downtown Annual Report 2013. London, Ontario. Retrieved from http://www.london.ca/business/Planning-Development/downtown/Documents/2013-CoL$\%$ 20State-of-the-\%20Downtown-\%20Report.pdf

City of London \& Downtown London (2014). Downtown Millennium Plan - 15 Years Later.

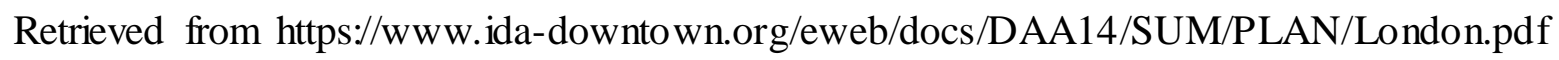

Daniszewski, H. (2012, Aug 1). Towering Demand for Units as Project Nears Completion. The London Free Press. Retrieved from http:/www.lfpress.com/news/london/2012/07/31/20050541.html

Filion, P., Hoernig, H., Bunting, T., Sands, G. (2004). The Successful Few: Healthy Downtowns of Small Metropolitan Regions. Journal of the American Planning Association, 70(3): 328-343. Retrieved from http:/geography.ssc.uwo.ca/faculty/gilliland/Filion_et_al_2004_downtowns.pdf

Ford, L.R. (2003). America's New Downtown: Revitalization or Reinvention? Baltimore: John Hopkins University Press.

Gad, G., \& Matthew, M. (2000). Central and Suburban Downtowns, in Bunting, T, Filion, P (Eds.), Canadian Cities in Transition: the Twenty-first Century, 2nd Edition (p. 248-275). Toronto: Oxford University Press.

Grant, J. (2000). Planning Canadian Cities: Context, Continuity, and Change, in Bunting, T, Filion, P (Eds.), Canadian Cities in Transition: the Twenty-first Century, 2nd Edition (p. 443461). Toronto: Oxford University Press.

Hume, G. (2014). Places and Spaces. Union: Municipal World.

Jamieson, W., Cosijn, A. \& Friesen, S. (2000). Contemporary Planning: Issues and Innovations, in Bunting, T, Filion, P (Eds.), Canadian Cities in Transition: the Twenty-first Century, 2nd Edition (p. 462-478). Toronto: Oxford University Press. 
Jones, K. (2000). Dynamics of the Canadian Retail Environment, in Bunting, T, Filion, P (Eds.), Canadian Cities in Transition: the Twenty-first Century, 2nd Edition (p. 404-423). Toronto: Oxford University Press.

McLeod, P. (2014). Millennium Award for Downtown. The McLeod Report. Retrieved from $\mathrm{http} / / /$ hemcleodreport.ca/news-events/1388- millennium-award-for-downtown.html

Meyers, S. (2014). London High-Rise Project to Change Face of Downtown. London Community News. Retrieved from http:/www.londoncommunitynews.com/news-story/4900616-londonhigh-rise-project-to-change-face-of-downtown/

Olson, S. (2000). Form and Energy in the Urban Built Environment, in Bunting, T, Filion, P (Eds.), Canadian Cities in Transition: the Twenty-first Century, 2nd Edition (p. 224-244). Toronto: Oxford University Press.

Smith, P.J. (2000). Suburbs, in Bunting, T, Filion, P (Eds.), Canadian Cities in Transition: the Twenty-first Century, 2nd Edition (p. 303-332). Toronto: Oxford University Press.

Taylor-Butts, A (2009). "Household Income and Victimization in Canada, 2004." Crime and Justice Research Paper Series. Statistics Canada Catalogue no. 85F0033M - No. 20. Ottawa. http://www.statcan.gc.ca/pub/85 f0033m/85f0033m2009020-eng.pdf (accessed September 5, 2016) 